\title{
Unified Solutions on Plastic Limit Internal Pressure for Metallic Elbows
}

\author{
Q. Zhu, ${ }^{1}$ J. H. Zhao, C. G. Zhang, Y. Li, and S. Wang \\ School of Civil Engineering, Chang'an University, Xi'an, China \\ ${ }^{1}$ huqianchd@126.com
}

УДК 539.4

\section{Комплексное решение задачи расчета внутреннего давления и предела пластичности для металлических колен}

\author{
К. Джу, Дж. Х. Джао, С. Г. Джанг, Я. Ли, С. Ванг \\ Факультет гражданского строительства, Чанганский университет, Сиянь, Китай
}

\begin{abstract}
На базе комплексной теории прочности проанализирована пластичность металлического колена при внутреннем давлении с учетом промежуточного главного напряжения и различной прочности при растяжении и сжатии. Получены комплексные решения для колен с одинаковой и разной толщиной стенок и локальным утонением. С иелью изучения влияния параметра комплексной теории прочности, степени растяжения-сжатия, коэффициента изгиба и толщины стенок проведено параметрическое исследование. Сравнительный анализ расчетных и экспериментальных данных показал хоромее их соответствие. Установлено, что при расчете металлическх колен комплексные решения многофункциональны, о чем свидетельствуют полученные результаты. Учет промежуточного главного напряжения позволил выявить скрытые потенциальные возможности металлических колен. Комплексные решения имеют важное практическое значение для оптимального проектирования и технического применения металлических колен.
\end{abstract}

Ключевые слова: комплексная теория прочности, металлические материалы, колено, предельное внутреннее давление.

Introduction. Elbows are complex components with spatially curved surfaces, which are generally used for joining straight pipes and are mainly subjected to the internal pressure [1-3]. Elbows are composed of high-strength steel or filament-wound composite materials with different strength values in tension and compression [4-8].

The plastic limit pressure of metallic elbows in the available literature is analyzed by using either the Tresca or Mises yield criteria, or the finite element analysis. Ma et al. [9] derived the plastic limit pressure formula and analyzed the plastic performance of an elliptical elbow of variable wall thickness using the Tresca and Mises yield criteria. Duan et al. [10] discussed the ultimate pressure of elbows with a local thinned area on the inner wall of extrados via the finite element analysis. Guo et al. [11] particularly emphasized the plastic collapse load analysis of undefected elbows under the complex loads, such as internal pressure, moment and torsion. However, the Tresca and Mises yield criteria are only applicable to isotropic materials and not suitable to anisotropic materials in tension and compression. In addition, the Tresca yield criterion does not take into account the intermediate principal stress effect.

Strength potentialities of metallic elbows are better achieved with consideration of the intermediate principal stress and different strength values in tension and compression. The plastic performance of elbows with a constant and variable wall thickness values and those 
with a local thinning are discussed based on the unified strength theory (UST). The unified solutions are derived for elbows. The strength effects of various parameters are analyzed.

Methods: Unified Strength Theory. The UST consideres the effects of intermediate principal stress and can be applied to a variety of materials. Considering two larger principal shear stresses and the corresponding normal stress, the mathematical expression can be expressed as [12]:

$$
\begin{array}{ccc}
F=\sigma_{1}-\frac{\alpha}{1+b}\left(b \sigma_{2}+\sigma_{3}\right)=\sigma_{s} & \text { when } & \sigma_{2} \leq \frac{\sigma_{1}+\alpha \sigma_{3}}{1+\alpha}, \\
F^{\prime}=\frac{1}{1+b}\left(\sigma_{1}+b \sigma_{2}\right)-\alpha \sigma_{3}=\sigma_{s} & \text { when } & \sigma_{2} \geq \frac{\sigma_{1}+\alpha \sigma_{3}}{1+\alpha},
\end{array}
$$

where $\alpha$ and $b$ are defined as $\alpha=\sigma_{s} / \sigma_{c}$ and $b=\frac{(1+\alpha) \tau_{s}-\sigma_{s}}{\sigma_{t}-\tau_{s}}, \sigma_{1}, \sigma_{2}$, and $\sigma_{3}$ are major, intermediate, and minor principal stresses, respectively, $\alpha$ is a tension-compression strength ratio, $\sigma_{s}, \sigma_{c}$, and $\tau_{s}$ are tensile, compressive, and shear yield strength values of the material, respectively, and $b$ is the unified strength theory parameter that reflects the influence of the intermediate principal stress and also the parameter of failure criterion for $0 \leq b \leq 1$.
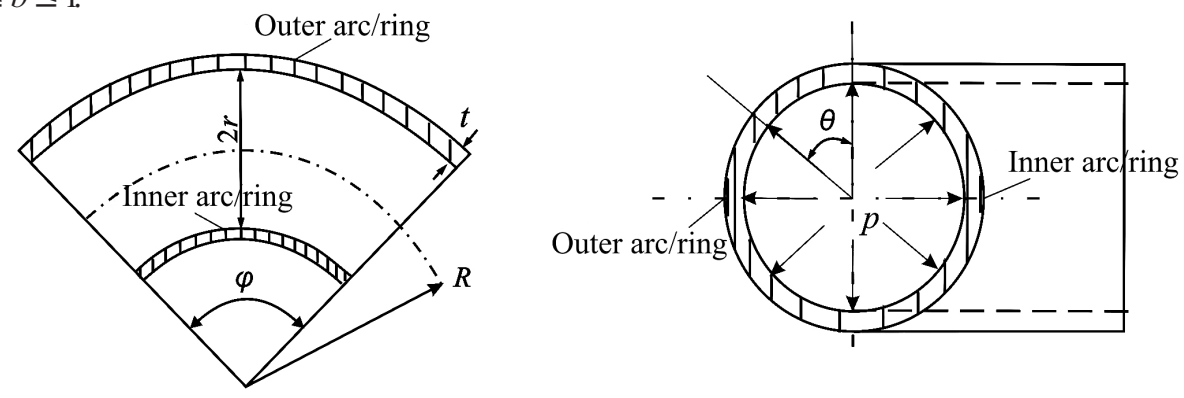

Fig. 1. An elbow subjected to internal pressure.

Mechanical Analysis: Plastic Limit Internal Pressure. Elbows with a Constant Wall Thickness. Figure 1 shows an elbow with bending radius $R$, inner diameter $2 r$, and wall thickness $t$, which is subjected to internal pressure $p$. The elbow is regarded as a part of toroidal shells without considering the influence of the edge stress. The equations of circumferential stress and longitudinal stress can be written as

circumferential stress:

$$
\sigma_{\theta}=\frac{p r}{2 t} \frac{2 R+r \sin \theta}{R+r \sin \theta}
$$

longitudinal stress:

$$
\sigma_{\varphi}=\frac{p r}{2 t}
$$

The circumferential stress $\sigma_{\theta}$ is the maximum value in the inner arc/ring, i.e., $\theta=-90^{\circ}$, which can be presented as follows:

$$
\sigma_{\theta}=\frac{p r}{2 t} \frac{2 R-r}{R-r} .
$$


The radial stress along the wall thickness direction can be negligible, as compared to the circumferential stress and longitudinal stress, i.e., $\sigma_{\theta} \geq \sigma_{\varphi} \geq \sigma_{r}$. The stress state of longitudinal cross section reaches the plastic limit state first with the pressure increased. The corresponding pressure is the plastic limit internal pressure of an elbow with a constant wall thickness $p_{u 1}$. The principal stress in the inner arc/ring $\left(\theta=-90^{\circ}\right)$ can be given as

$$
\sigma_{1}=\sigma_{\theta 1}=\frac{p r}{2 t} \frac{2 R-r}{R-r}, \quad \sigma_{2}=\sigma_{\varphi 1}=\frac{p r}{2 t}, \quad \sigma_{3}=\sigma_{r 1}=0 .
$$

Since $\sigma_{2}=\frac{p r}{2 t} \leq \frac{\sigma_{1}+\alpha \sigma_{3}}{1+\alpha}=\frac{\sigma_{1}}{1+\alpha}$, Eq. (1a) should be used. Then Eq. (1a) can be reduced to

$$
\sigma_{\theta 1}-\frac{\alpha b}{1+b} \sigma_{\varphi 1}=\sigma_{s}
$$

Substituting (5) into (6), the plastic limit internal pressure can be reduced to

$$
p_{u 1}=\frac{2 \sigma_{s} t}{r} \frac{(1+b)(R-r)}{(2+2 b-\alpha b) R-(1+b-\alpha b) r} .
$$

According to (7), the plastic limit internal pressure of an elbow with a constant wall thickness can be written as follows:

(1) The plastic limit internal pressure can be formulated as $p_{u 1}=\frac{2 \sigma_{s} t(R-r)}{r(2 R-r)}$ based on the Tresca yield criterion [9], i.e., $b=0, \alpha=1$.

(2) The plastic limit internal pressure can be written as $p_{u 1}=\frac{2.732(R-r) \sigma_{s} t}{2.366 R r-r^{2}}$ based on the Mises yield criterion [9], i.e., $b=1 /(1+\sqrt{3}), \alpha=1$.

(3) The plastic limit internal pressure can be expressed as $p_{u 1}=\frac{4 \sigma_{s} t(R-r)}{r[(4-\alpha) R-(2-\alpha) r]}$ based on twin shear strength theory [13], i.e., $b=1$.

Elbows with a Variable Wall Thickness. According to the concept of plastic deformation with a constant volume, the wall thickness $t_{\theta}$ of an elbow with a variable wall thickness can be determined ignoring the transverse shrinkage deformation as [14]:

$$
t_{\theta}=\frac{R t_{0}}{R+r \sin \theta}
$$

where $t_{0}$ is the restraint stress for the original wall thickness.

Substituting Eq. (8) into Eqs. (2) and (3), the stress can be written as

$$
\begin{gathered}
\sigma_{\theta 2}=\frac{p r}{t_{0}}\left(1+\frac{r \sin \theta}{2 R}\right), \\
\sigma_{\varphi 2}=\frac{p r}{2 t_{0}}\left(1+\frac{r \sin \theta}{R}\right) .
\end{gathered}
$$

The circumferential stress $\sigma_{\theta}$ is the maximum value attained in the outer arc/ring of the elbow with a variable wall thickness, i.e., $\theta=90^{\circ}$. The stress state of outer arc/ring 
cross section reaches the plastic limit state first. The corresponding pressure is the plastic limit internal pressure of the elbow with a variable wall thickness $p_{u 2}$.

The principal stress in the outer arc/ring can be rewritten as

$$
\sigma_{1}=\sigma_{\theta 2}=\frac{p r}{t_{0}}\left(1+\frac{r}{2 R}\right), \quad \sigma_{2}=\sigma_{\varphi 2}=\frac{p r}{2 t_{0}}\left(1+\frac{r}{R}\right), \quad \sigma_{3}=\sigma_{r 2}=0 .
$$

In view of $\sigma_{2}=\frac{p r}{2 t}\left(1+\frac{r}{R}\right) \leq \frac{\sigma_{1}}{1+\alpha}$, Eq. (1a) should be used. Then Eq. (1a) can be reduced to

$$
\sigma_{\theta 2}-\frac{\alpha b}{1+b} \sigma_{\varphi 2}=\sigma_{s}
$$

Substituting (11) into (12), the plastic limit internal pressure $p_{u 2}$ can be reduced to

$$
p_{u 2}=\frac{2 \sigma_{s} t_{0} R(1+b)}{2 R r+r^{2}+b \operatorname{Rr}(2-\alpha)+b r^{2}(1-\alpha)} .
$$

According to (13), the plastic limit internal pressure of an elbow with a variable wall thickness can be expressed as follows:

(1) $p_{u 2}=\frac{2 \sigma_{s} t_{0} R}{2 R r+r^{2}}$ based on the Tresca yield criterion [9], i.e., $b=0, \alpha=1$.

(2) $p_{u 2}=\frac{2.732 \sigma_{s} t_{0} R}{2.366 R r+r^{2}}$ based on the Mises yield criterion [9], i.e., $b=1 /(1+\sqrt{3})$, $\alpha=1$.

(3) $p_{u 2}=\frac{4 \sigma_{s} t_{0} R}{\operatorname{Rr}(4-\alpha)+r^{2}(2-\alpha)}$ based on the twin shear strength theory [13], i.e., $b=1$.

Elbows with a Local Thinning. Many researchers have carried out the investigation of the plastic limit loading of elbows with a local thinning. The plastic limit internal pressure formula in [10] is derived based on the Tresca yield criterion through numerical analysis and data fitting. The respective formula proposed in this paper is based on the UST and can be reduced to the following:

$$
p_{u 3}=\frac{2 \sigma_{s} t}{r} \frac{(1+b)(R-r)}{(2+2 b-\alpha b) R-(1+b-\alpha b) r} f\left(a, b_{1}, c\right),
$$

where $\quad f\left(a, b_{1}, c\right)=\min (g, 0.954), \quad g=18.483 G^{2}-7.108 G+1.023, \quad G=a^{0.5} b_{1}^{0.1} c^{3}$ (application range: $G<0.21)$. Here, $f\left(a, b_{1}, c\right)$ is the correction coefficient, $a, b_{1}$, and $c$ are the dimensionless parameters, i.e., $a=\gamma / 45^{\circ}, b_{1}=\theta / 180^{\circ}$, and $c=C / t, \gamma$ is the defective radial half-angle, $\theta$ is the defective circumferential half-angle, and $C$ is the defect depth of the local thinned area (as shown in Fig. 2).

Results and Discussion. Experimental Verification. Based on the elbow dimensions and material parameters from $[10,15]$, the comparison of limit internal pressure values obtained in this paper via Eqs. (7) and (14) with the experimental data are shown in Tables 1 and 2, respectively. One can observe that the calculation results are in a good agreement with the experimental data.

Influence Factor Analysis. The bending coefficient $m$ is defined as $m=r / R$. Substituting the formula into Eqs. (7) and (13), parametric studies are carried out to 
$\mathrm{T}$ a b 1 e 1

\section{Comparison of Literature Data and Calculation Results}

\begin{tabular}{|c|c|c|c|c|c||}
\hline \multirow{2}{*}{ No. } & Dimensions & Bending radius & \multicolumn{2}{|c|}{ Limit internal pressure (MPa) } & Comparison \\
\cline { 2 - 5 } & $\begin{array}{c}\varphi \times t \\
(\mathrm{~mm} \times \mathrm{mm})\end{array}$ & $R, \mathrm{~mm}$ & $\begin{array}{c}\text { Literature data } \\
p_{s}\end{array}$ & $\begin{array}{c}\text { Calculation } \\
\text { results } p_{u 1}\end{array}$ & $p_{s} / p_{u 1}$ \\
\hline $1 \#$ & $108 \times 3$ & 100 & 15.21 & 15.86 & 0.9589 \\
$2 \#$ & $108 \times 5$ & 100 & 26.80 & 27.33 & 0.9805 \\
$3 \#$ & $108 \times 8$ & 100 & 46.00 & 45.97 & 1.0006 \\
$4 \#$ & $108 \times 10$ & 100 & 60.27 & 59.42 & 1.0144 \\
\hline $5 \#$ & $108 \times 3$ & 150 & 18.33 & 19.40 & 0.9446 \\
$6 \#$ & $108 \times 5$ & 150 & 31.47 & 33.17 & 0.9487 \\
$7 \#$ & $108 \times 8$ & 150 & 52.62 & 55.17 & 0.9538 \\
$8 \#$ & $108 \times 10$ & 150 & 67.74 & 70.79 & 0.9569 \\
\hline 9\# & $108 \times 3$ & 175 & 19.03 & 20.28 & 0.9383 \\
$10 \#$ & $108 \times 5$ & 175 & 33.05 & 34.63 & 0.9545 \\
$11 \#$ & $108 \times 8$ & 175 & 55.92 & 57.47 & 0.9731 \\
$12 \#$ & $108 \times 10$ & 175 & 71.04 & 73.64 & 0.9647 \\
\hline $13 \#$ & $108 \times 3$ & 200 & 20.25 & 20.91 & 0.9685 \\
$14 \#$ & $108 \times 5$ & 200 & 33.79 & 35.66 & 0.9475 \\
$15 \#$ & $108 \times 8$ & 200 & 57.07 & 59.11 & 0.9655 \\
$16 \#$ & $108 \times 10$ & 200 & 72.48 & 75.68 & 0.9577 \\
\hline
\end{tabular}

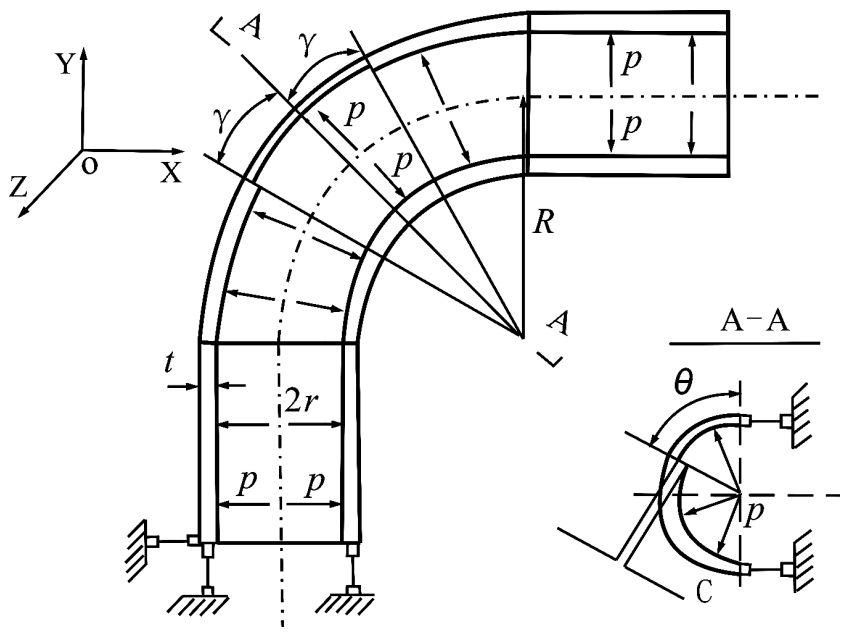

Fig. 2. The mechanical model.

investigate the influence of the bending coefficient $m$, wall thickness $t$, tensioncompression ratio $\alpha$, and the unified strength theory parameter $b$ on the plastic limit internal pressure $p_{u 1}$ and $p_{u 2}$ (Figs. 3-5).

The plastic limit internal pressure $p_{u 1}$ dependences on the bending coefficient $m$ and wall thickness $t$ are plotted in Fig. 3. The analysis is conducted using $b=0$ and $\alpha=1$. Figure 3 shows that limit pressure increases with wall thickness and decreases with the bending coefficient. The difference of results is smaller with the increase of bending coefficient $m$ when $m$ varies from 0.2 to 0.8 . When $m$ is close to 0 , the plastic limit pressure formula yields the same results as the one for a straight pipe. 
Unified Solutions on Plastic Limit Internal Pressure ...

$\mathrm{T}$ a b 1 e 2

Comparison of Literature Data and Calculation Results

\begin{tabular}{|c|c|c|c|c|c|c||}
\hline \multirow{2}{*}{ No. } & \multicolumn{3}{|c|}{ Dimensions } & \multicolumn{2}{c|}{ Limit internal pressure (MPa) } & Comparison \\
\cline { 2 - 7 } & $a$ & $b_{1}$ & $c$ & $\begin{array}{c}\text { Literature data } \\
p_{L}\end{array}$ & $\begin{array}{c}\text { Calculation } \\
\text { results } p_{u 3}\end{array}$ & $p_{L} / p_{u 3}$ \\
\hline 01 & 0.05 & 0.10 & 0.10 & 52.23 & 47.54 & 0.9103 \\
02 & 0.05 & 0.25 & 0.25 & 52.30 & 47.54 & 0.9090 \\
03 & 0.05 & 0.40 & 0.50 & 52.25 & 42.55 & 0.8143 \\
04 & 0.05 & 0.50 & 0.75 & 26.44 & 26.94 & 1.0189 \\
\hline 05 & 0.125 & 0.10 & 0.25 & 52.24 & 47.54 & 0.9101 \\
06 & 0.125 & 0.25 & 0.10 & 52.25 & 47.54 & 0.9099 \\
07 & 0.125 & 0.40 & 0.75 & 19.92 & 19.83 & 0.9956 \\
08 & 0.125 & 0.50 & 0.50 & 43.08 & 37.83 & 0.8782 \\
\hline 09 & 0.25 & 0.10 & 0.50 & 36.28 & 35.67 & 0.9831 \\
10 & 0.25 & 0.25 & 0.75 & 17.91 & 16.99 & 0.9489 \\
11 & 0.25 & 0.40 & 0.10 & 52.29 & 47.54 & 0.9092 \\
12 & 0.25 & 0.50 & 0.25 & 51.78 & 47.54 & 0.9182 \\
\hline 13 & 0.375 & 0.10 & 0.75 & 17.71 & 17.08 & 0.9644 \\
14 & 0.375 & 0.25 & 0.50 & 34.85 & 31.47 & 0.9029 \\
15 & 0.375 & 0.40 & 0.25 & 51.05 & 47.54 & 0.9313 \\
16 & 0.375 & 0.50 & 0.10 & 52.03 & 47.54 & 0.9138 \\
\hline \hline
\end{tabular}

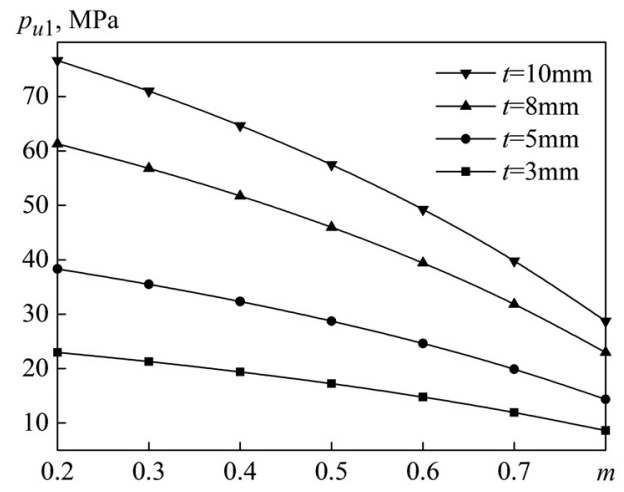

Fig. 3

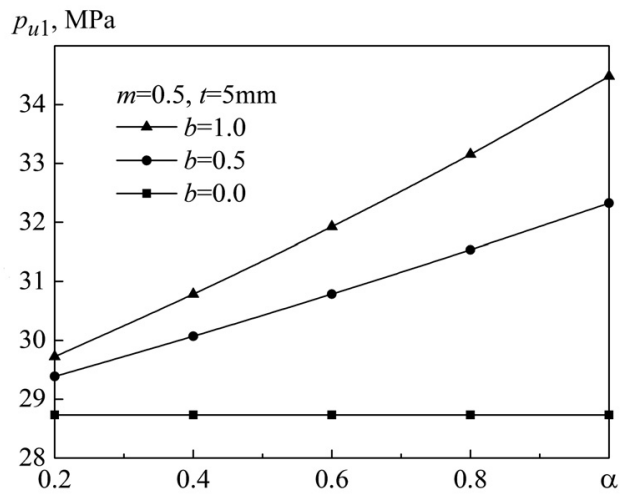

Fig. 4

Fig. 3. Limit pressure $p_{u 1}$ versus coefficient $m$ and wall thickness $t$.

Fig. 4. Limit pressure $p_{u 1}$ versus coefficients $\alpha$ and $b$.

The unified strength theory (UST) parameter can continuously vary from 0 to 1 . For each condition, three different values of $b(0,0.5$, and 1) are considered (Fig. 4). As is shown in Fig. 4, the limit pressure can enhance with the increase of the UST parameter $b$. It indicates that the influence of the UST parameter, bending coefficient and other factors is necessary to consider.

The limit pressure curve of an elbow with a variable wall thickness is illustrated in Fig. 5. It can be seen from Fig. 5 that the limit pressure $p_{u 2}$ decreases with the bending coefficient $m$ and increases with the UST parameter $b$. It can be observed that the proper choice of the yield criterion for the limit pressure is critical for the metallic elbow design. 


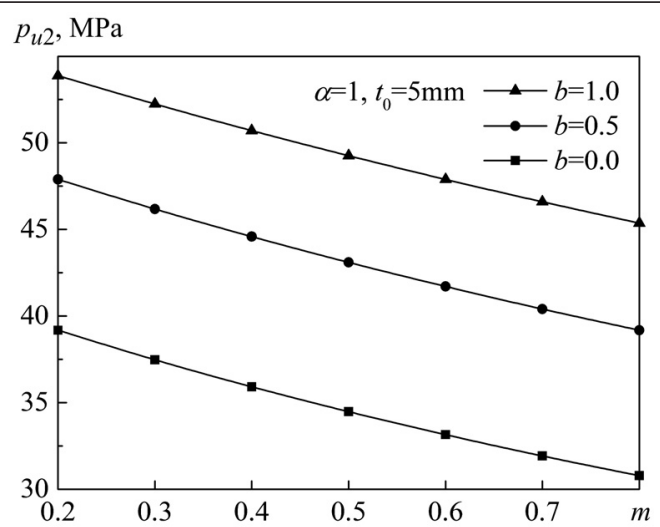

Fig. 5. Limit pressure $p_{u 2}$ versus coefficients $b$ and $m$.

Conclusions. With consideration of the intermediate principal stress and different strength values in tension and compression, the unified solution of plastic limit internal pressure for metallic elbows is conducted based on the unified strength theory. The influence of each parameter is analyzed. Parametric studies are carried out to investigate the influence of the unified strength theory parameter $b$, tension-compression ratio $\alpha$, bending coefficient $m$, and wall thickness $t$. The unified solutions are versatile in the theory of metallic elbows, which can either be reduced to the existing formula, or provide a series of new solutions. The solutions based on the Tresca and Mises yield criteria, and on the twin shear strength theory are the special cases. The results obtained show that the plastic limit internal pressure is stringly affected by the unified strength theory parameter and bending coefficient. Strength potentialities of metallic elbows can be fully achieved due to considering the intermediate principal stress.

Acknowledgments. This research was supported by the Shaanxi Provincial Natural Science Foundation (Grant No. 2011JM7002), the National Natural Science Foundation of China (Grant No. 41202191), the Fundamental Research Funds for the Central Universities (Grant No. 2013G2283007) and the Special Researc Foundation of Higher Education Doctoral Program (Grants No. 20110205130001 and No. 20120205120001).

\section{Резюме}

На базі комплексної теорії міцності проаналізовано пластичність металічного коліна при внутрішньому тиску з урахуванням проміжного головного напруження і різної міцності при розтязі і стиску. Отримано комплексні розв'язки для колін, що мають одинакову і різну товщину стінок і локальне стоншення. Із метою вивчення впливу параметра комплексної теорії міцності, ступеня розтягу-стиску, коефіцієнта згину і товщини стінок проведено параметричне дослідження. Порівняльний аналіз розрахункових і експериментальних даних показав хорошу їх відповідність. Установлено, що при розрахунку металічних колін комплексні розв'язки є багатофункціональними, про що свідчать отримані дані. Урахування проміжного головного напруження сприяло вивченню прихованих потенційних можливостей металічних колін. Комплексні розв'язки мають важливе практичне значення для оптимального проектування і технічного використання металічних колін.

1. J. Yi, T. Wen, X. Q. Yan, and J. L. Yu, "Stress intensity factors of bend with circumferential through cracks under internal pressure," Mach. Des. Manuf., 51, No. 8, 95-97 (2013). 
2. S. H. Zhang, D. W. Zhao, and C. R. Gao, "Analysis of plastic collapse load of defect-free pipe elbow with GM criterion," J. Northeast Univ. (Nat. Sci.), 32, No. 11, 1570-1573 (2011).

3. S. P. Hong, J. H. Kim, and Y. J. Kim, "Effect of internal pressure on plastic loads of 90 elbows with circumferential part-through surface cracks under in-plane bending," Eng. Fract. Mech., 77, No. 4, 577-596 (2010).

4. Y. J. Kim, J. Kin, J. Ahn, et al., "Effects of local wall thinning on plastic limit loads of elbows using geometrically linear FE limit analyses," Eng. Fract. Mech., 75, No. 8, 2225-2245 (2008).

5. K. M. Prabhakaran, A. Srivastava, and A. K. Ghosh, "Plastic collapse moment of 90 long radius elbows with internal circumferential surface crack at intrados under in-plane bending," Int. J. Press. Vess. Piping, 88, No. 9, 269-280 (2011).

6. H. T. Cui, W. D. Wen, and L. L. Tong, "Strength analysis of filament-wound pipe," Aerosp. Mater. Technol., 43, No. 6, 39-42 (2003).

7. J. J. Han, K. H. Lee, N. H. Kim, et al., "Comparison of existing plastic collapse load solutions with experimental data for 90 elbows," Int. J. Press. Vess. Piping, 89, No. 1, 19-27 (2012).

8. Y. J. Kim, J. H. Je, C. S. Oh, et al., "Plastic loads for 90 thick-walled elbows under combined pressure and bending," J. Strain Anal. Eng. Des., 45, No. 2, 115-127 (2010).

9. J. H. Ma and F. X. Zhu, "Plastic limit load analysis of elbows under the internal pressure," Mech. Eng., 34, No. 5, 48-51 (2012).

10. Z. X. Duan and S. M. Shen, "Finite element analysis of plastic limit pressure of elbows with local thinned area on inner wall of extrados," Nucl. Power Eng., 27, No. 6, 52-55 (2006).

11. C. X. Guo, X. S. Wang, and D. B. Wang, "Plastic collapse load analysis of undefected pipe elbows under the complex loads," Press. Vess. Technol., 18, No. 4, 8-12 (2001).

12. M. H. Yu, Unified Strength Theory and Its Applications, Springer Press, Berlin (2004).

13. Z. Yue and N. Jiang, "Calculation and finite element analysis of plastic limit load for elbow based on twin-shear-stress theory," Process Equip. Pip., 48, No. 5, 40-43 (2011).

14. Y. Wu, "Stress calculation of high pressure bend pipe," Chem. Eng. Des., 16, No. 4, 25-26 (2006).

15. Z. X. Duan and S. M. Shen, "Analysis and experiments on the plastic limit load of elbows under internal pressure," Press. Vess. Technol., 21, No. 8, 1-4 (2004). 